\title{
Challenges Posed by Ageing to Financial and Monetary Stability
}

\author{
E. Philip Davis \\ Department of Economics and Finance, Brunel University, Uxbridge, Middlesex, UB3 4PH, U.K. \\ E-mail: e_philip_davis@msn.com
}

In common with other OECD countries and some emerging market economies (EMEs), pension reform is essential for the future stability of the EU in general and EMU countries in particular. Its progress is of major concern to central banks as well as Ministries of Finance. We have highlighted a number of risks to financial stability that may occur due to ageing itself (with pension reform) and notably when there is a continued reliance on unsustainable pay-as-you-go pension systems. There are also challenges for counterinflation monetary policy during the ageing process, as at different points it may generate deflationary and inflationary pressures, while a fiscal crisis would have major repercussions for monetary stability. The transmission process of monetary policy will also enter a state of flux with ageing, although arguably this may be sufficiently gradual to allow policymakers time to adapt. On the other hand, we detect a negative effect of ageing on productivity, which if substantiated offers a deeper challenge both to stability and living standards as ageing progresses.

The Geneva Papers (2005) 30, 542-564. doi:10.1057/palgrave.gpp.2510048

Keywords: ageing; pension systems; monetary policy; financial stability

JEL classification: E44; E58; H55; J10

\section{Introduction}

All OECD countries and a growing number of emerging market economies (EMEs) face economic and financial challenges as their populations age. More specifically, against the background of forthcoming population ageing, the Lisbon Agenda and later EU pronouncements have challenged Member States to meet coming challenges in this field, with aims such as "to carry out pension reforms to ensure adequate pensions, financial sustainability and modernity of the retirement systems in the long run". The process of such pension reform is well advanced in the New Member States of the EU, albeit much less so in many of the "older" ones. Consequently, as noted by Regling and Costello ${ }^{1}$ of the European Commission, "a clear and unequivocal risk of unsustainable public finances exists in at least half of EU Member States". Attempts

\footnotetext{
* An earlier version of this paper was presented at the Austrian Central Bank Economics Conference, Vienna, 27-28 May 2004. We thank Jean-Claude Chouraqui, Edi Hochreiter, Chris Martin and Klaus Schmidt-Hebbel for helpful comments. The three consecutive sections following Introduction draw partly on work prepared for a Deutsche Bundesbank conference in 2001 (Davis, 2002).

${ }^{1}$ Regling and Costello (2003).
} 
to raise effective retirement ages, also required for a sustainable response to ageing, have been even less successful to date.

Whereas ageing is inevitable and pension reform is essential for fiscal sustainability, the literature on the economic and financial implications of such developments is in our view unbalanced. There is extensive work on fiscal implications of ageing and pension systems. ${ }^{2}$ The link between changing demographic structure and macroeconomic performance has also been widely studied. ${ }^{3}$ Furthermore, there is a growing field of work on financial implications of ageing. ${ }^{4}$

On the other hand, work on implications of ageing and pension systems for central-bank policy, both in the field of monetary and financial stability, is rather poorly developed. Against this background, this paper seeks to probe the implications of ageing itself, of a "no-reform" scenario and of the growth of pension funds following a successful reform, for financial stability and counter-inflationary aims of monetary policy. It draws on existing work on macroeconomic, fiscal and financial implications, but seeks to illustrate how they could also combine to render the task of central banking more complex as the ageing process accelerates, depending on the scope of reform. Whereas we focus mainly on the EU, the issues identified are of wider relevance to other OECD countries and ageing EMEs (which include China). We maintain that recent Japanese experience with economic and financial instability accompanying sharply accelerated ageing is illuminating, while acknowledging that other factors, including policy errors, played a role in that country.

\section{Effects of ageing on macroeconomic performance}

Essential background is the overall impact of ageing on macroeconomic performance in OECD countries. We may summarize current views on the latter as follows:

As regards GDP growth, it is widely considered that it will decelerate as ageing proceeds, principally because of lower labour-force growth. There will also be lower growth in living standards (i.e. GDP per head) than has been the case in recent decades, reflecting the accompanying increase in the dependency ratio. Effects on growth of a fall in labour force growth are unlikely to be offset by higher investment. Indeed, investment is itself likely to decline given a lesser need for capital widening, while capital deepening is likely to be limited by diminishing returns. Moreover, slower economic growth will tend to reduce returns on capital directly, thus again putting downward pressure on investment. The example of slower Japanese output and investment growth since 1970, and accompanying lower returns to capital, may be cited in this context as being partly linked to demographic shifts. Lower private and public saving (with high government borrowing), as discussed below, may crowd out investment. On the other hand, higher labour-force participation - which could be

\footnotetext{
${ }^{2}$ See Dang et al. (2001) for a recent example.

${ }^{3}$ See for example Turner et al. (1998); Kohl and O'Brien (1998); McMorrow and Roeger (2003).

${ }^{4}$ Such as Poterba $(2001,2004)$ and other studies surveyed in Davis and Li (2003).
} 
stimulated by pension reform ${ }^{5}$ - could help to underpin growth. Another unknown factor in this context is the response of productivity of labour or capital to ageing and its impact on economic growth discussed further below.

An important element in assessing private saving is the view taken of the life-cycle hypothesis, which postulates initial dissaving in young adulthood, followed by saving for retirement and finally dissaving in retirement. Most estimates of the determination of saving based on macro evidence suggest that this pattern holds, implying that an older population will save less. For example, Masson and Tryon ${ }^{6}$ found an elasticity of -1 from the dependency ratio to the savings rate using pooled cross-section and timeseries data for industrial countries, although later work by Masson $\mathrm{et} \mathrm{al.}{ }^{7}$ and Loayza et $a l^{8}{ }^{8}$ reduced this estimate to around -0.2 . McMorrow and Roeger ${ }^{9}$ found an average elasticity of -0.75 across existing studies. The implication is that ageing will sharply reduce private saving. Note however that the process may not be monotonic, since peak saving is usually by those in later working life. Hence, in the current decade saving may increase as the baby-boom generation reaches maturity and saves for retirement; saving will then fall when baby-boomers retire.

Micro-results are much more equivocal in terms of the life-cycle, with much evidence suggesting that the elderly may not save less than the working population. ${ }^{10}$ Furthermore, the negative effect on saving may be partly attenuated by pension reform. Disney ${ }^{11}$ offers evidence that reform of public pension systems may have the effect of boosting private saving, also highlighting a study of Italy, ${ }^{12}$ which supports the hypothesis. Furthermore, and more tentatively, funding should tend to reduce the cost and increase the availability of equity and long-term debt financing to companies (entailing financial deepening), and hence may raise productive ${ }^{13}$ capital formation. ${ }^{14}$ Economically efficient capital formation could in turn raise output and "endogenously" raise growth itself. ${ }^{15}$ Higher growth will, of course, feed back on saving.

As the population ages, the public sector will tend to lower its saving, ceteris paribus. Such trends in public saving are largely driven by the scale of the public pension system in the light of ageing and the means of financing adopted (e.g. taxation vs. debt finance).${ }^{16}$ Debt finance would imply a greater fall in public saving. Rapid increases in the proportion of the population over the age of 65 years (the dependency ratio)

\footnotetext{
${ }^{5}$ A shift to funding should reduce the distortion to labour markets induced by taxes on labour linked to pay-as-you-go.

${ }^{6}$ Masson and Tryon (1990).

${ }^{7}$ Masson et al. (1995).

${ }^{8}$ Loayza et al. (2000).

${ }^{9}$ McMorrow and Roeger (2003).

${ }^{10}$ Poterba (2001).

${ }^{11}$ Disney (2000).

12 Attanasio and Brugiavini (1999).

${ }^{13}$ This also requires allocation of funds to their most profitable uses and adequate shareholder-monitoring of the investment projects, which should also tend to occur in capital markets dominated by pension funds.

${ }^{14}$ Davis (2004b).

${ }^{15}$ Holzmann (1997).

${ }^{16}$ Recent estimates include those in Dang et al. (2001); McMorrow and Roeger (2002).
} 
combined with generous social security pension schemes are particularly threatening. It is this aspect that is encouraging governments to scale down public pension commitments and switch to funding. If, as suggested above, funding also boosts private saving, the benefit to domestic saving is compounded.

External balances will be driven by the combination of domestic saving and investment. ${ }^{17}$ After an initial surplus as baby-boomers reach peak saving (as recently in the case of Japan), it is generally accepted that ageing will lead to a greater fall in saving than investment, implying balance-of-payments deficits that may themselves entail exchange rate pressures.

Illustrating these patterns, Turner et $a l .{ }^{18}$ provided a simulation of the global effects of population ageing (focusing both on changing population growth and age structure), using the OECD's international dynamic general equilibrium macromodel MINILINK. Reflecting the declining labour supply with ageing, economic growth is forecast to decline to 0.25 per cent per annum in Japan, 1 per cent in Europe and 1.4 per cent in the United States by around 2030. The slowdown in growth reduces investment needs directly. Furthermore, a decline in the weight of the OECD in the world economy tends to improve OECD current accounts (and hence savinginvestment balances) as non-OECD imports rise faster than OECD import demand. The U.S., Europe and Japan all generate balance-of-payments surpluses of 2-3 per cent of GDP up to 2025, as saving is initially boosted by the high proportion of highsaving age groups while growth potential and hence investment weaken, thus building up net external assets that help to buttress GNP.

On the other hand, eventual downwards pressures on public and private saving are greater in the OECD than elsewhere, generating - in combination with exchange rate appreciation - deficits for the three OECD regions after 2025. As world investment in this simulation falls less than savings, world real interest rates are expected to rise slightly, reinforcing the decline in investment. Reflecting differing returns on capital, interest rates are higher in EMEs than in the OECD. The authors note that higher saving in OECD countries could generate quite different results, with lower real interest rates and consequently higher investment and capital-labour ratios. There would also be greater net external assets, boosting OECD GNP via inflows of interest, profits and dividends. ${ }^{19}$ As we noted above, some limited boost to saving could be anticipated from a switch from pay-as-you-go to funding.

Note that the above is just one example of global projections - others differ in details. For example, McMorrow and Roeger ${ }^{20}$ concur that the EU and Japan will run surpluses for some time, but expect the U.S. to run ongoing deficits, reflecting growth differentials and an assumption that the absorptive capacity of slow-ageing EMEs is limited. They also note that such a continued concentration of capital flows within the OECD is more likely to generate downward pressure on rates of return and a risk of bubbles.

\footnotetext{
${ }^{17}$ See Bikker (1996).

18 Turner et al. (1998).

${ }^{19}$ The return on such investments will depend on factors such as labour and product market reforms in the EMEs as well as the overall size of such flows from the OECD (if the flows are sufficiently sizeable, they will depress the return on capital in the EMEs).

${ }^{20}$ McMorrow and Roeger (2003).
} 
546

\section{Ageing, the no-reform case and financial stability}

With the above macroeconomic projections as background, we now go on to assess risks for financial stability that could concern central banks. It is clear that ageing which is most acute in Europe (and Japan) among OECD countries - will generate sharp changes in quantities and prices in EU financial markets As discussed in Davis, ${ }^{21}$ and against the background of the previous section, a possible effect on financial stability can be traced for the "general case" of ageing and for countries where pay-as-you-go remains dominant as well as where funding is introduced (see the following two sections). Generally, these entail partly predictable patterns in financial markets, which nevertheless may overshoot and/or entail instability when they take place. Such instability is obviously of major interest to central banks. No system is likely to be unscathed, but issues are far more serious for pay-as-you-go.

Looking first at financial stability issues linked to the general case of ageing, as noted, it is widely anticipated that saving will rise in the next few years owing to the "baby-boom generation" entering peak saving age, while potential growth declines. Then, like Japan in the 1980s and 1990s, the EU could face an external surplus and loss of competitiveness with currency appreciation, aggravated by home bias due to uncertainty on the part of pension funds. This may, in turn, generate excess liquidity and loose macroeconomic policies (if a structural surplus is mistaken for a cyclical one). In turn, this could generate a financial bubble (as already observed in Japan), whose deflation entails financial instability. Later, as baby-boomers retire, there could be a balance-of-payments deficit, with risks of currency crises and exchange rate volatility accompanying banking crises.

The volatility in external flows and asset prices would be ameliorated by growthpromoting domestic policies (such as boosting the labour supply, raising saving and investment, and reforms seeking to increase productivity) that would limit savinginvestment imbalances. Policies to improve the absorption capacity of slow-growing poorer countries as in Africa would ensure that flows are not kept largely within the OECD. ${ }^{22}$ This is in a sense a "first best solution" that is in the interests of central banks to encourage. However, some volatility seems inevitable, which would require careful monitoring by central banks. It may need a greater focus on asset price movements and monitoring of lending during periods of asset price volatility. Lender of last resort provision would of course not necessarily be an appropriate response in the case that the volatility generates insolvency rather than illiquidity.

Risks in pay-as-you-go may be best traced in the extreme case of no-reform. They will be attenuated to the extent that reforms reducing benefits and/or increasing effective retirement ages take place. One aspect is that the inevitable uncertainty about future pensions in unreformed systems will lead to heightened precautionary saving. If directed to banks, this may lead to underpricing of risk in domestic credit or international interbank markets, again as in Japan, ${ }^{23}$ with similar implications for

\footnotetext{
${ }^{21}$ Davis (2002).

22 McMorrow and Roeger (2003).

${ }^{23}$ See Hargraves et al. (1993).
} 
financial stability. Life insurers could invest in high-yield bonds and property and be vulnerable to credit cycles, with consequences also for their solvency.

Turning to fiscal effects themselves, if there is tax finance when ageing occurs (i.e. a marked rise in contribution rates), there may be major economic difficulties owing to the adverse effects of high and distortionary taxes on economic performance, generating credit losses and falls in asset prices, which are unlikely to be accurately anticipated by lenders. Underlying and accompanying these problems, capital as well as labour could translocate from the country concerned, especially if the tax burden is weighted towards these factors of production, as opposed to being in the form of consumption taxes.

In the case of bond finance (i.e. whereby governments run deficits and accumulate debts when there is strain on pay-as-you-go systems during ageing), one may in due course expect a sharp rise in long-term interest rates, loss of credit rating of the government, crowding-out and a recession. Hence, major credit losses for lenders may arise as borrowers face adverse economic conditions and higher interest costs. We note that most past fiscal crises, as in Italy, were with unliberalized banking systems, and hence are not a sufficient prediction of likely consequences. In this context, the government's ability to recapitalize banks in difficulty would decline with its borrowing capacity and credit rating. Ultimately, as interest rates rise and growth falls while deficits rise and debts accumulate, there may be a fiscal-solvency crisis, which could be contagious, "snowball" and give rise to a temptation to monetize, or leave EMU. There would obviously be major challenges to the financial stability responsibilities of central banks as well as monetary stability difficulties (see the section on Pension funds, ageing and inflation). All of the adverse effects will, of course, take place at an earlier stage if governments fail to consolidate the fiscal position in advance of the onset of ageing.

The pension issue linked to unreformed pay-as-you-go is arguably the most intractable one facing the single currency. Given the need to finance the transition, even a country reforming a generous social security system and shifting to funding will not entirely escape some of these difficulties outlined for pay-as-you-go. It is worth noting that an unintended side effect of the Stability and Growth Pact may be to dissuade countries from reforming in a systemic manner, as that typically requires an accounting "transition deficit" to redistribute the burden across generations. Meanwhile, countries that have reformed would suffer from higher long-term interest rates and other adverse spillovers in the case of a crisis elsewhere.

\section{Pension funds, financial structure and financial stability}

We now turn to implications of pension reform for financial stability. A realistic scenario, as suggested by McMorrow and Roeger ${ }^{24}$ is partial replacement of social security by funded pensions, with contributions to the former frozen at current levels as a proportion of wages, and current pension promises made up by appropriate

\footnotetext{
${ }^{24}$ McMorrow and Roeger (2002).
} 
funding. Such a reform would markedly ease the fiscal burden of ageing, reducing the risks outlined above, and would also tend both to boost private saving and change the size and composition of household asset accumulation.

As noted by McMorrow and Roeger, ${ }^{25}$ a significant proportion of extra asset accumulation generated by a partial shift to funding in the EU would be invested internationally, with a benefit in terms of interest income accruals and also risk diversification. This proportion will be markedly higher if EU countries do not undertake labour and product market reforms necessary to make it attractive to invest domestically. Growth of pension funds following reform is also likely to entail a partial displacement of other forms of saving, ${ }^{26}$ notably bank deposits, leading to an acceleration of the shift in EU financial systems from bank and loan basis to a securitized and institutional investor basis. ${ }^{27}$

In general, a financial system characterized by institutional investors and extensive capital market financing may be more stable than a bank-based one, especially if there is a mispriced safety net protection in the latter and low values of banking charters. For in normal times, pension funds, having good information and low transactions costs, are likely to speed the adjustment of asset prices to fundamentals; this should entail price volatility only to the extent that fundamentals are themselves volatile. Moreover, the diversity in types and sizes of institutional investors - in their liabilities, incentives, and consequent attitudes to risk - should be stabilizing to financial markets. The liquidity that institutional activity generates may dampen volatility, as is suggested by lower share price volatility in countries with large institutional sectors. ${ }^{28}$

It can, moreover, be argued that securitized financial systems have important stabilizing features, such as ease of marking to market, matched assets and liabilities and - notably for mutual funds and defined contribution pension funds - distance from the safety net. There are wider opportunities to diversify and spread risk. Furthermore, the "multiple channels of intermediation" available to the corporate sector in securitized financial systems will reduce the impact of any crises that affect either banks or securities markets. ${ }^{29}$

On the other hand, notably during the transition, risks may arise for the banking sector following pension reform. Disintermediation, with a lesser proportion of saving being channelled via banks, given lower deposit inflows and greater competitiveness of capital market financing, may give rise to banking crises. This is because banks in such a situation may take increased risks so as to boost their profitability in a highly competitive market situation, while higher quality credits seek capital-market financing. Indeed, it can be argued that the banking crises in a number of countries in the late 1980s were linked to the heightened competition banks faced from the capital markets. ${ }^{30}$ Again there are precedents in Japan. ${ }^{31}$ In this context, note that

\footnotetext{
${ }^{25}$ McMorrow and Roeger (2003).

${ }^{26}$ Boersch-Supan and Winter (2002).

${ }^{27}$ Davis (1999b).

${ }^{28}$ Davis and Steil (2001).

${ }^{29}$ See Greenspan (1999); Davis (2001).

${ }^{30}$ Davis and Steil, op. cit.

${ }^{31}$ Hoshi et al. (1993).
} 
a number of authors such as Demirguc-Kunt and Detragiache ${ }^{32}$ have looked at the effect of financial liberalization on systemic risks, and found that banking crises were more likely to occur in liberalized financial systems. Crises tended to occur a few years after liberalization, and were linked to a decline in bank franchise value, because monopoly power is eroded. ${ }^{33}$ Securities market competition driven by growth of pension funds can arguably have a similar effect to deregulation on franchise values and risk taking. A number of EU banking systems already suffer from low profitability and excess capacity and could be vulnerable in this context. ${ }^{34}$ The traditional instruments of emergency liquidity assistance, as well as fiscal headroom for bailouts, could be called upon if such risks materialize.

Pension funds and other institutional investors which are vehicles for retirement saving may also give rise to unfamiliar types of financial instability from the point of view of regulators and market players, which would be accentuated as they grew during the expansion of precautionary saving and/or funding. These would pose challenges to central banks in terms of adaptation of macroprudential analysis ${ }^{35}$ and response to crises. Already in the existing experience of financial instability, one can distinguish two particular types of financial turbulence they give rise to:

A first type involves extreme market-price volatility after a shift in expectations and consequent changes in institutional investors' asset allocations. Such crises are focused mainly on the consequences for financial institutions of sharp price changes that result from institutional "herding", as groups of such institutions imitate one another's strategies for reasons related to the information and agency problems between the investors and the asset managers. ${ }^{36}$ Whereas misaligned asset prices and sharp price movements during corrections may not in themselves have systemic implications, ${ }^{37}$ these may emerge when such movements threaten, for example, financial institutions that have taken leveraged positions on the current levels of asset prices. Examples are the stock market crash of 1987, the ERM crisis, the 1994 bond market reversal and the Mexican crisis. ${ }^{38}$ There were also elements of this in the Asian crisis. Indeed, EME securities markets, as well as those for forex, derivatives, bonds and equities in OECD countries, could be vulnerable to these shifts, not least if a large proportion of pension financing is directed to EMEs. The challenge, here, is the appropriate monetary policy response to the preceding misalignment, as well as possible need for emergency liquidity assistance for institutions facing difficulty after the adjustment.

A second type involves protracted ${ }^{39}$ collapse of market liquidity and issuance. ${ }^{40}$ Again often involving one-way selling by institutional investors as they seek to shift

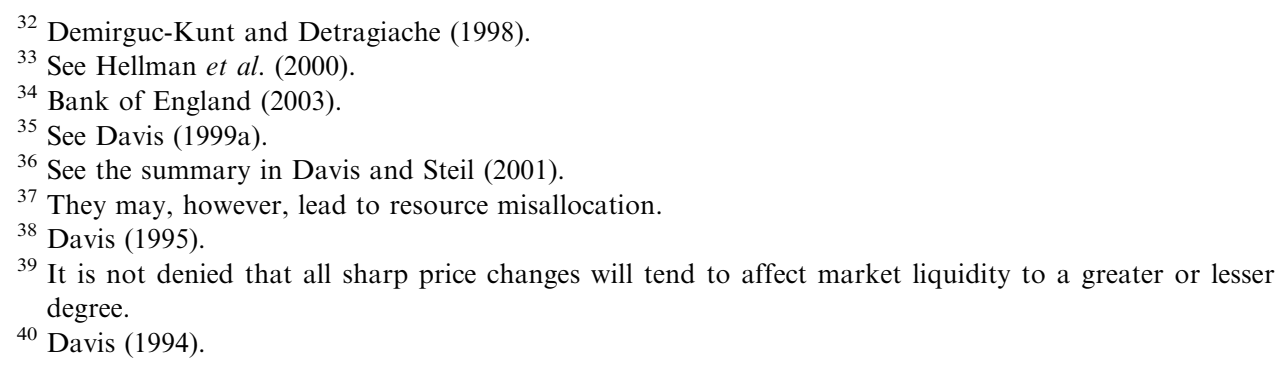


asset allocations simultaneously, the distinction is often largely one of whether markets are sufficiently resilient, and whether market maker structures are suitably robust. Also, such crises tend to characterize debt markets rather than equity or foreign exchange. The risks are acute not only for those holding positions in the market but also for those relying on the market for debt finance or liquidity - which increasingly includes banks. Examples in the past have tended typically to be rather specific and idiosyncratic markets, which by nature relied on a narrow investor base, market maker structure and/or issuer base (junk bonds, floating rate notes, Swedish commercial paper, ECU bonds). Central banks have tended justifiably to leave the market to sort out its own difficulties. However, the events following the Russian default and the rescue of the hedge fund LTCM were much more serious, as liquidity failure was threatened in markets such as the U.S. repo, swaps, CP, corporate and Treasury bond market. ${ }^{41}$ U.S. monetary policy makers cut rates repeatedly in the wake of the crisis, partly out of concern that borrowers from bond markets would not find sufficient lending capacity from banks. In this context, note that real-estate crises, which could also follow institutional herding, have elements of illiquidity as well as price declines.

Owing to their impact on the availability and price of credit, as well as liquidity of assets, price-volatility- and market-liquidity-based crises may threaten EMEs, banks and the nonfinancial sector more than pension funds and other institutional investors themselves. These could naturally be matters of central-bank concern. Long-term institutions can "sit out" such crises given their long-term liabilities.

But institutional investors may also tend to focus increasingly on debt claims as members approach retirement, while competition in asset management may also lead investment managers to be willing to take heightened credit risks in order to maximize their return on assets. ${ }^{42}$ In countries such as the U.S., defined benefit pension funds have pension benefit insurance that may generate significant moral hazard. ${ }^{43}$ This suggests that institutional investors could increasingly invest in high-yield bonds and EME sovereign and corporate debt, and thus be vulnerable to credit risk to a greater extent than was the case in the past. Credit cycles could, in other words, affect institutional investors as well as banks. Solvency could be threatened directly for life insurance companies and defined benefit pension funds if a significant proportion of their assets defaulted. Equally, besides market and credit risk, errors on the asset or liability side (e.g., in terms of guaranteed returns or mortality projections) could also threaten solvency of a range of institutional investors, as has been seen already in Japan and with certain U.K. companies such as Equitable Life. ${ }^{44}$

Three points may mitigate related systemic concerns. (1) Insurance companies and defined benefit pension funds are not easily subject to runs on suspicion of insolvency, given they have matched and long-term assets and liabilities, while mutual funds and defined contribution pension funds are not themselves subject to solvency risks -

\footnotetext{
${ }^{41}$ See IMF (1998); Davis (1999a).

${ }^{42}$ Bishop (1998); Allen and Gale (1999).

43 Bodie and Merton (1992).

${ }^{44}$ See IMF (2001); Davis (2004a).
} 
credit risks are passed directly to the household sector. (2) Most institutional-investor claims are not insured, or the insurance is mutual, thus generating incentives for interfirm monitoring. (3) Given the ease of adopting market value accounting for securitized claims, it can be argued that debt crises are much less likely in corporate bond markets than for banks where the deterioration of credit quality is hidden from view in the balance sheet. ${ }^{45}$ Markets can still make mistakes however, as witness to the repeated bond-based debt crises of the late Victorian period, and U.S. experience suggests that bond markets generally find rescheduling after financial distress difficult. ${ }^{46}$ Furthermore, whereas central banks may not be directly concerned with insolvency of institutions per se (since they are not subject to panic runs), they may be concerned about abrupt changes in saving levels and saving patterns that could accompany loss of confidence in long-term institutions.

\section{Pension funds, asset prices and financial stability}

Beyond the changing nature of the financial system, the expanded asset flows from pension saving during ageing, as foreshadowed in the section on effects of ageing on macroeconomic performance, may entail financial instability in terms of volatility of asset prices, which agents in the economy may not correctly anticipate.

There is evidence of such patterns from recent financial history. It is widely suggested that asset flows from institutions driven by ageing may have driven the last bull market in equities in countries such as the U.S. ${ }^{47}$ Work on savings flows such as Poterba's ${ }^{48}$ does imply that high levels of retirement saving in the form of securities may have driven up market prices. It may be the case that the institutionalization of saving has boosted equity prices via a fall in the risk premium, ${ }^{49}$ reflecting better diversification and lower risk aversion of collective investment vehicles. Such tendencies can overshoot, leading to bubbles. On the other hand, most work on the relation of equity prices to mutual fund flows suggests that direct effects of inflows on prices are hard to detect. ${ }^{50}$

While the above discussion is largely focused on equities, asset bubbles could also accompany the pension asset build-up to the extent that retirement investment focuses on debt or real-estate claims. The property market might be particularly susceptible. Finance of property development by bond issue or direct institutional investment are two possible channels. This could leave insurers as well as banks vulnerable to a downturn in the property cycle, as was the case in the Jamaican insurance crisis of 1996. ${ }^{51}$ Following Allen and Gale, ${ }^{52}$ if institutions become significantly involved in property investment and related credit finance, the massive inflows to pension funds as

\footnotetext{
45 Davis (2001).

${ }^{46}$ Gilson et al. (1990).

${ }^{47}$ Shiller (2000).

${ }^{48}$ Poterba (2001).

49 Blanchard (1993).

${ }^{50}$ Fortune (1998); Engen and Lehnert (2000).

51 IMF (2001).

52 Allen and Gale (1999, 2000).
} 
well as insurance companies could generate expectations of ongoing boosts to credit flows into property. There may also be increasing uncertainty about future such flows as ageing progresses. These in the past have tended to foreshadow asset bubbles generated by such credit flows. Externalities in commercial property lending are significant, owing to the effect of new construction on the profitability of contiguous buildings. Since banks would remain exposed to property prices via collateral and would probably also lend to higher-risk projects, ${ }^{53}$ they could be badly hit when decumulation occurs, or earlier if institutional investors seek to adjust their asset allocation away from property for any reason.

A large share of OECD pension saving invested in EMEs can also lead to bubbles and financial stability risks in the latter owing to institutional behaviour, even before an eventual repatriation of funds. Owing, for example, to autonomous shocks affecting national or regional profitability and creditworthiness, such as local wars, there may be flight of investable funds back to the OECD or to other EMEs. In this context, note that securities are in principle much easier to repatriate than bank loans. Indeed, behaviour of OECD institutional investors is already widely considered to destabilize EMEs, not least owing to their tendency to invest in EMEs as a bloc rather than focusing closely on individual countries' fundamentals. ${ }^{54}$ These patterns of volatility are underpinned by the sharp difference in relative size of EMEs and OECD institutional investors, which may expand as pension funds grow during population ageing.

Beyond the issue of changing asset allocation decisions, which can drive price falls even if pension saving is still rising, there are also arguments suggesting that asset prices will fall during the process of ageing itself, as it interacts with pension funding. A fundamental aspect is that the return on capital may fall as a consequence of a lower labour supply and lower growth during ageing; for example, Cutler et al. ${ }^{55}$ see the real return on capital halving. An issue for funding is whether it can generate offsetting increases in efficiency and resource allocation, for example, via growth of capital markets, which may help to offset this by boosting productivity and investment.

Besides the return on physical capital, a key issue is whether asset prices will also be put under downward pressure in coming decades by declining saving or allocation of funds to equities in OECD countries implicitly affecting the real interest rate or the risk premium. Brooks ${ }^{56}$ argues that because there is a smaller generation of investors to sell their assets to, this would put downward pressure on asset prices. Also there will be excess demand for bonds and excess supply of equities in coming decades, as the elderly take annuities or seek safe assets with a marked decline in the returns on the retirement savings of baby-boomers held in equities. Schieber and Shoven ${ }^{57}$ developed a similar argument suggesting that in the future, defined benefit pension systems will become net sellers, while the structure and pattern of flows from defined benefit pension plans means asset prices will be depressed. Poterba, ${ }^{58}$ although he

\footnotetext{
${ }^{53}$ Davis and Zhu (2004).

54 Buckberg (1996).

${ }^{55}$ Cutler et al. (1990).

56 Brooks (2000).

${ }^{57}$ Schieber and Shoven (1994).

58 Poterba (2001, 2004).
} 
acknowledges that standard models suggest that equilibrium returns on financial assets will vary in response to changes in population age structure, argues that the rapid meltdown hypothesis is inconsistent with empirical survey data. Consumers decumulate assets at a less rapid rate than the life cycle suggests. This is because the life-cycle model takes no account of the bequest motive and lifetime uncertainty. Hence, although asset demands have risen to fuel the recent boom, future declines will be modest. However, Abel, ${ }^{59}$ using a rational expectations model, which took account of the bequest motive, found stock prices are still expected to fall when baby-boomers retire despite high projected asset demands owing to shifts in the supply of capital in response to changes in its price.

Davis and $\mathrm{Li}^{60}$ give econometric evidence that demographics have had a significant impact on the U.S., panel and aggregated international stock prices and bond yields, even in the presence of standard additional independent variables. ${ }^{61} \mathrm{We}$ reproduce a table of their results below for the U.S., showing that the 40-64 (AGE40) cohort has a strong important positive influence on asset prices (negative on bond yields), a support that would be removed as its share of the population declines (Table 1).

Meanwhile Chart 1, which follows, shows that results shown above with the $65+$ cohort (AGE65) excluded do not indicate a substantial weakening of asset prices in the coming decades. The share price rises sharply in the period up to 2010 , then increases fall back while remaining above zero. The bond yield falls to remain around 2 per cent up to 2025. On the other hand, Chart 2 shows that with AGE65 included, the equity price is set to decline from 2015 onwards, while the real interest rate rises to historic peaks only previously seen in the early 1980s. These tentative results, including estimated effects of the over-65 cohort in the U.S., suggest that a more severe downturn is possible, thus underlining the potential market risks associated with sole reliance on fully funded pension schemes.

In this context, solvency could be threatened for life insurance companies and defined benefit pension funds that had made undertakings based on expected returns on assets formed during the bull period (as has been the case recently for the Japanese life insurers and pension funds ${ }^{62}$ ).

Of course, the "meltdown" highlighted above might be attenuated, although central banks would still need to be vigilant for shorter-term financial stability risks during this process. One attenuating factor is the growing, maturing and wealth of populations of EMEs such as China, India and Brazil in the coming decades, who would purchase shares sold in OECD countries. Productivity improvements as the population ages could offset declines in the return on equity owing to demand side factors, as suggested by Cutler et al., ${ }^{63}$ although our own results presented in the

\footnotetext{
59 Abel (2001).

${ }^{60}$ Davis and Li (2003).

${ }^{61}$ As noted by Poterba (2004), our study "moves beyond most of the previous work in including control variables for nondemographic factors that may affect asset prices, such as the rate of economic growth, the inflation rate, and the recent volatility of the equity market. The findings are robust to the inclusion of these control variables."

${ }^{62}$ See Fukao (2002).

${ }^{63}$ Cutler et al. (1990).
} 
The Geneva Papers on Risk and Insurance - Issues and Practice

554

Table 1 Demographic effects on real stock prices and bond yields for the U.S. (1950-1999)

\begin{tabular}{lccc}
\hline $\begin{array}{l}\text { Independent } \\
\text { variables }\end{array}$ & $\begin{array}{c}\text { Log difference of U.S. } \\
\text { real stock prices }\end{array}$ & $\begin{array}{c}\text { Independent } \\
\text { variables }\end{array}$ & $\begin{array}{c}\text { U.S. real } \\
\text { bond yields }\end{array}$ \\
\hline Constant & $-2.97(0.64)^{* *}$ & Constant & $12.3(4.0)^{* *}$ \\
AGE20 & $-0.0024(0.0098)$ & AGE20 & $0.266(0.052)^{* *}$ \\
AGE40 & $0.108(0.02)^{* *}$ & AGE40 & $-0.239(0.084)^{* *}$ \\
DYHP & $-3.4(6.5)$ & DSR & $0.628(0.1)^{* *}$ \\
DDIFY & $-1.28(0.97)$ & TS(-1) & $-0.73(0.125)^{* *}$ \\
RLR & $0.03(0.009)^{* *}$ & DLCPI $(-1)$ & $-109.1(9.7)^{* *}$ \\
VOL & $-1.19(0.62)^{*}$ & DDLCPI & $-142.6(10.0)^{* *}$ \\
DY (-1) & $0.092(0.026)^{* *}$ & DYHP & $-197.3(58.9)^{* *}$ \\
& & DDIFY & $-5.8(6.4)$ \\
$R^{2}$ & 0.54 & & 0.98 \\
RSS & 0.58 & & 4.9 \\
SE of regression & 0.12 & & 0.4 \\
$F$-statistic (7,50) & $6.0(0.0)^{* *}$ & & $102.9(0.0)^{* *}$ \\
Wald test for exclusion of & $15.2(0.0)^{* *}$ & & $16.2(0.0)^{* *}$ \\
AGE40 & & & 0.97 \\
$R$-bar-squared & 0.45 & & $1.8(0.19)$ \\
Serial correlation (2) & $1.1(0.36)$ & & $0.045(0.97)$ \\
Normality & $1.53(0.28)$ & & $0.06(0.81)$ \\
Heteroscedasticity & $0.53(0.47)$ & & $1.98(0.14)$ \\
Stability (RESET) & $2.4(0.09)^{*}$ & & $0.74(0.67)$ \\
Stability (Chow forecast) & $0.81(0.62)$ & & -3.7 \\
Unit root test & -5.9 & & \\
\hline & & & \\
DDIFY, & & & \\
\end{tabular}

DDIFY, difference of log difference of real GDP from HP filter; DYHP, trend growth derived from HP filter on log difference of real GDP; DY, dividend yield; DLCPI, log difference of CPI index; DLRSP, log difference of real share prices, derived as nominal share index divided by CPI; RLR, real bond yield, derived as nominal yield to maturity less current CPI inflation; VOL, real equity price volatility, derived as variance of log of monthly change in share prices divided by CPI within each year; AGE20, population aged 20-39 years as a per cent of the total; AGE40, population aged 40-64 years as a per cent of the total; AGE65, population $65+$ as a per cent of the total, DSR, first difference of the nominal short term interest rate, TS, term structure (long rate less short rate); DDLCPI, acceleration of the CPI index (log second difference). Standard errors in parentheses, except for diagnostics where the $P$-values are shown. * indicates significance at $90 \%$ and $* *$ indicates significance at $95 \%$. Serial correlation test is the LM (2) test; normality is the Jarque Bera statistic; heteroskedasticity is ARCH (1); stability is the RESET (3) test and the Chow forecast test over 1990-1999; unit root is the ADF.

section below suggest ageing worsens productivity. Monetary policy may be expected to respond to high real interest rates by an appropriate loosening, which will help attenuate the peaks. ${ }^{64}$ Investor demand would be likely to switch in the light of relative returns, for example to buy high-yield bonds in the later years. Neuberger ${ }^{65}$ argues that the increase and subsequent decrease in flows will be balanced by rises and falls in equity issues, with little effect on prices and returns. Young ${ }^{66}$ notes that demographics

\footnotetext{
${ }^{64}$ Poterba (2001).

${ }^{65}$ Neuberger (1999).

${ }^{66}$ Young (2002).
} 

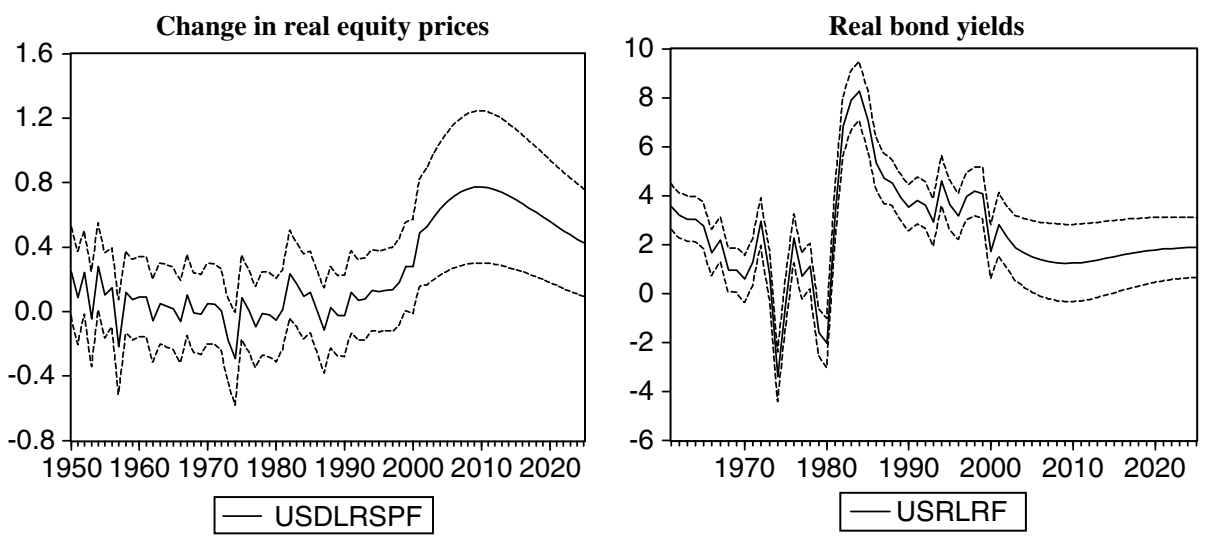

Chart 1. Projected U.S. asset prices for equations excluding AGE65 (source, Davis and Li (2003)). (Dashed lines are forecast standard errors.)
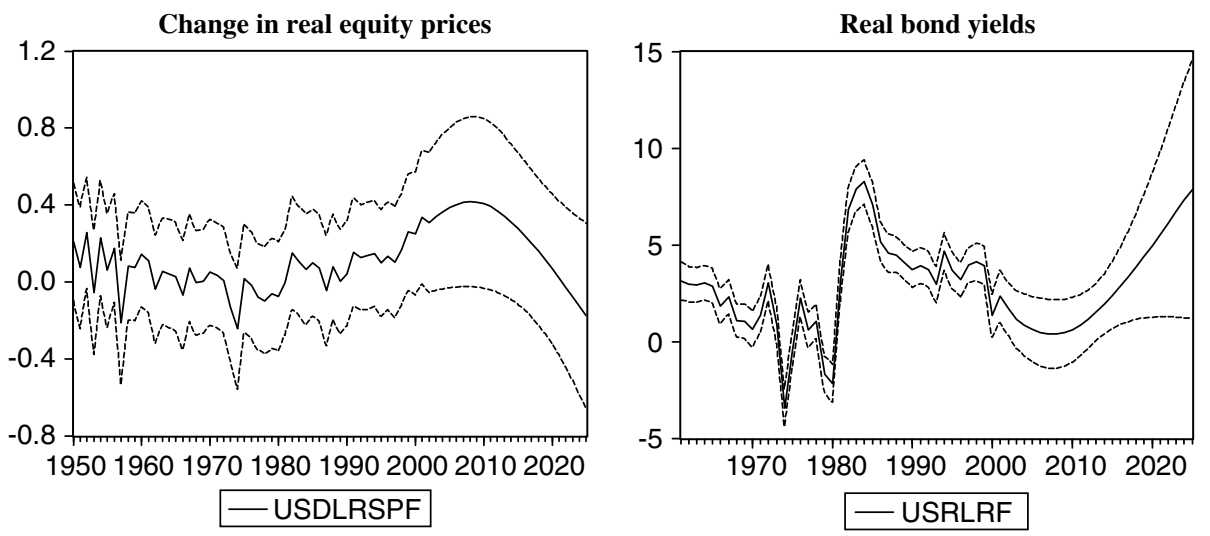

Chart 2. Projected asset prices for equations including AGE65 (source, Davis and Li (2003)). (Dashed lines are forecast standard errors.)

are only one determinant of asset prices and their effect may be overwhelmed by other changes (although the equations in Table 2 seek to allow for other determinants). Finally, since financial markets tend to be efficient and forward looking, and because demographic changes are slow moving and predictable, the market meltdown could be forestalled with rational expectations.

In general, we are sympathetic to the view that even if there are price changes with the decumulation of pension funds, they will not necessarily be precipitate, and hence the issue may be one affecting the level of retirement income and the welfare of pensioners rather than systemic financial market stability. On the other hand, the tendency of markets to overreact in both directions is apparent from the recent boom in IT stock prices, and hence vigilance is needed. If there are indeed such sharp changes in market prices during ageing, they may give rise to losses threatening 
solvency on the part of financial institutions or investors taking leveraged positions, possibly requiring emergency liquidity assistance. It would also impact on the adequacy of funding and replacement rates offered by pension funds and lifeinsurance companies. In countries where pension saving is not compulsory, inflows to pension funds and aggregate saving per se could become volatile as households react to uncertainty. A sharp shift away from securities could extend to other asset markets, notably those for commercial property and possibly to residential property. These effects would be compounded if, for example, the older population had a lower demand for housing services. Mankiw and Weil,${ }^{67}$ for example, made controversial ${ }^{68}$ projections of lower house prices in the U.S. as a consequence of ageing. The banks, which hold such property as security, would find credit quality declining as a consequence.

\section{Pension funds, ageing and inflation}

The implications of pension funds for monetary stability have also to be seen in the context of the macroeconomic effects set out in the first section. We divide them into challenges in respect of ageing per se and possible changes in the monetary policy transmission process. We note that this is an area where extant applied work as well as theoretical work is quite scarce; in our view, further research is needed in a number of areas.

To begin, we may note that experience of countries such as Japan has shown that an ageing population may for some time entail an increased savings propensity, especially if there is uncertainty about future pensions. Notably, if combined with lower potential growth owing to lack of structural reforms and ongoing problems in the banking system, this may entail downward pressure on consumer prices. Central banks concerned then have the issue of dealing appropriately with deflation, which Japanese experience shows is complex, especially if combined with a lax fiscal situation. More generally, the elderly are often seen as averse to inflation due to holdings of fixed income securities and hence should lend political support to counter-inflationary monetary policy.

On the other hand, we have also noted that older households will tend to dissave under a standard life-cycle approach to consumption over a lifetime. In due course, this implies a lower overall saving propensity for an ageing population. Depending on the behaviour of investment and net trade, this could entail excess demand ${ }^{69}$ If ageing leads to excess demand for goods and services, then there is likely to be enhanced inflationary pressures. This may be aggravated if current account deficits from lower saving entail downward pressure on the exchange rate. These would require a tight monetary stance to offset them.

Excess demand may be aggravated if there is a shrinkage on the supply side, with a decline in output growth from ageing owing to a smaller workforce, which is not offset

\footnotetext{
${ }^{67}$ Mankiw and Weil (1989).

${ }^{68}$ Engelhardt and Poterba (1991) and Hendershott (1991) provide counter-evidence to this suggestion.

${ }^{69}$ Fitoussi (2003).
} 
by increased capital formation. Indeed, it is suggested by Bonello ${ }^{70}$ that ageing is a negative supply shock, which is worsened if higher consumption tends to crowd out investment. This may be complemented in terms of inflationary pressures by a tighter labour market owing to ageing, as workers gain enhanced bargaining power because of their scarcity. The need for higher labour force participation and a higher effective retirement age is underlined, reversing the recent trend in the EU for those over the age of 55 years.

A key issue is whether productivity responds to ageing in a positive manner or not. If productivity were to respond positively to ageing, then higher wages may not entail inflation and excess demand will be attenuated. Higher productivity would also boost the demand for capital and sustain capital returns. Some authors suggest that ageing slows technical progress as innovation becomes less profitable with a shrinking market for capital goods and owing to the lesser dynamism of an ageing population. ${ }^{71}$ In contrast, Cutler et al. ${ }^{72}$ suggest that innovation increases as labour gets scarce. It is suggested by Disney ${ }^{73}$ that there is no link detectable from ageing to productivity, implying investment rates will be crucial to growth, not least given possible "endogenous" links from investment to productivity. (We present tentative results of our own below that support Wattenberg's pessimism.) The possible link of ageing to productivity nevertheless underlines the need for structural reform to permit growth in productivity, as well as raising investment and saving.

The supply shock may be reduced if there is an effect of pension reform on fixed investment, via greater supply of funds overall or greater provision of risk capital. Davis and $\mathrm{Hu}^{74}$ suggest that the latter is the more likely outcome. Growth of pension funds may also attenuate inflationary pressures if the use of bond investment makes, as noted, for political resistance to erosion of asset values. This effect would be much reduced if PAYG systems are not reformed. Then the pensions being indexed and "wealth" being largely in implicit claims, the population would be more relaxed about inflation.

If realized, the financial stability risks highlighted in the preceding two sections would generally tend to have a negative effect on inflation and could ultimately lead to challenges of deflation as in Japan. Some, such as short-term volatility, market liquidity and banking crises, could be dealt with by emergency liquidity intervention that is later sterilized. However, if there are major effects on the macroeconomy affecting inflation prospects, then interest rate policy may need to respond in a counter-cyclical manner. The possibility of an asset price collapse with ageing as outlined above is a much more protracted challenge and could need prolonged periods of low short-term interest rates. How this would interact with the potential inflationary pressures and excess liquidity would need careful judgement.

There is a particular threat to monetary stability in the case that there is bond finance of social security pension system (and health system) deficits, with no reform

\footnotetext{
${ }^{70}$ Bonello (2003).

${ }^{71}$ Wattenburg (1987).

${ }^{72}$ Cutler et al. (1990).

73 Disney (1996).

${ }^{74}$ Davis and $\mathrm{Hu}(2005)$.
} 
affecting spending such as lower benefits or a higher effective retirement age. Given the scope of projected increases in expenditures, such structural deficits could become extremely large as well as corresponding debt accumulation. Effects on monetary stability can be traced via the inflationary impact of deficit financing. At a basic level, deficits may generate excess demand and boost inflation if central banks "give in" to pressure to accommodate fiscal deficits by easing monetary policy, and households do not simply reduce expenditures to offset government spending in a Ricardian manner. Higher long-term interest rates accompanying large structural deficits would reduce investment, enhancing the supply shock of ageing and consequent inflation risks. When public debts are sufficiently high, such pressures may be complemented by political pressures from governments to accommodate deficits and ultimately to monetize the debt (recall that for very high debt levels, unsustainable debt dynamics can only be reversed for the inflation rate high enough, or if the interest rate is low enough). Note that tax finance would not necessarily avoid fiscal problems for monetary stability when tax rates rise to high levels, since "factor flight" would probably entail growing fiscal deficits as economic activity slows.

The standard assumption is that if central banks resist pressures to accommodate, then inflation will not rise, since inflation is a monetary phenomenon. This implies that governments will have to obey intertemporal budget constraints and ultimately reduce debts and deficits to sustainable levels. On the other hand, the literature also highlights the so-called "fiscal theory of the price level". ${ }^{75}$ It suggests that the price level adjusts in order to ensure the value of nominal government debt, is divided by the price level, and equals the real present value of future government surpluses. The so-called "nonRicardian" assumptions needed for this to apply are strong and controversial, ${ }^{76}$ while empirical work has not been strongly supportive. Nevertheless, the theory remains of potential importance since a corollary is that the burden of lax fiscal policies could overwhelm even stability-oriented monetary policies (in some papers, fiscal policy determines the price level independently of the path of the money supply). Given rational expectations, such an outcome would be perceived well ahead. ${ }^{77}$ Furthermore, there may be important spill-over effects from a country running an unsustainable fiscal policy in a Monetary Union. ${ }^{78}$ Certainly, past hyperinflations tended to be linked to unsustainable fiscal policies. Further work is, in our view, needed to assess the degree of applicability of the fiscal theory of the price level to the risks to unsustainable pension systems during ageing, given that these are the greatest fiscal challenges, and also that they are the most obvious case where the intertemporal budget constraint may be breached. At least, this risk to monetary stability further underlines the importance of pension reform.

Ageing may also alter the monetary transmission process, although arguably this will be sufficiently gradual to give central banks time to adapt. As noted by Miles, ${ }^{79}$ changes in interest rates are likely to have a different effect on consumption of young

\footnotetext{
${ }^{75}$ See Woodford (2001) and references.

${ }^{76}$ See Alfonso (2002) for a summary of criticisms.

${ }^{77}$ Salo (2003).

${ }^{78}$ Andres et al. (2002).

${ }^{79}$ Miles (2002).
} 
and old individuals. The former are more likely to be credit constrained, while interest rate changes will have the effect of changing the cost of consumption at different points in the life cycle. For older persons, the impact might arise more via asset price changes induced by monetary policy (the young own relatively few nonhuman assets). This asymmetric effect might be a marked feature if the elderly hold a larger proportion of bonds than equities in their portfolios, while the former are more affected by interest rates than the latter. When there is ageing, the channel of transmission to consumption would hence be more via wealth effects and less via credit constraints and intertemporal substitution.

Hence the population distribution would affect the impact of interest rates on consumption. Miles ${ }^{80}$ estimates that the impact on consumption both of a rise and decline in interest rates will be greater when the population ages, owing to the asset price effect being larger than the credit constraint and intertemporal substitution. Also, the impact will be greater, the further pension reform towards funding has been pursued, as this raises the stock of assets held and reliance on them for income by the elderly. ${ }^{81}$ This result relies on a sufficiently large wealth effect on consumption by the old as well as, perhaps, a lack of annuitization. It will be of particular importance, as reformed pension systems tend to be defined contributions. It implies that monetary policy, pace Miles, might come under pressure to take more account of asset price effects.

We noted above that inflationary pressures may accompany ageing. As discussed by Fitoussi, ${ }^{82}$ a continued high level of unemployment in Europe would limit wage pressures, although it would be expected that a fall in labour supply during ageing owing to retirement would facilitate absorption of the unemployed. An issue for the transmission mechanism in this context is whether ageing will increase the nonaccelerating inflation rate of unemployment (NAIRU) below which inflation rises rapidly. This might occur if, for example, an older workforce is less willing to move house or occupation in response to redundancy. Employers' high social security contributions could affect the NAIRU via labour demand.

The change in financial structure that is ongoing from bank to market-based intermediation ${ }^{83}$ will be accelerated by ageing, if it is accompanied by pension reform. This again raises an issue of adaptation by monetary policy makers because firms (and possibly households via securitization) will be financed by money and bond markets and not via banks. Different key interest rates and also scope of credit rationing (a lesser importance of the "credit channel") may be entailed. The issue of substitutability of bank and bond market finance will also become of major importance for monetary policymakers. ${ }^{84}$

Other transmission process changes can also be envisaged. Exchange rate dynamics will differ with large foreign assets of pension funds and their reallocation. Mortgage debt may be lower with a smaller younger generation, which will change the income

\footnotetext{
${ }^{80}$ Ibid.

${ }^{81}$ For estimates of future assets, see McMorrow and Roeger (2003).

${ }^{82}$ Fitoussi (2003).

${ }^{83}$ Davis (1999b, 2004b).

${ }^{84}$ Greenspan (1999).
} 
gearing effect of monetary policy, especially in countries where mortgages are floating rate. Money demand itself is likely to differ between young and old consumers, meaning ageing will change its characteristics.

Given the lack of research in this area, we considered it to be of interest to undertake some exploratory regressions on the relationship between age structure and selected key variables for monetary stability, namely inflation, growth, productivity and house prices. We have undertaken simple seemingly unrelated (SUR) panel regressions on seven major OECD countries, the U.K., U.S., Germany, Japan, Italy, Spain and France over 1950-2000 (1970-2000 for house prices). SUR is appropriate given likely contemporaneous correlations due to common economic shocks and feasible given that we are working with $N$ (number of cross-section observations) far below $T$ (time-series observations). The estimates utilize United Nations ${ }^{85}$ data on the size of age cohorts $20-39,40-64$ and 65 and over relative to the population as a whole. The residual is the young dependent cohort aged 0-19 years. These are the same data definitions as used in the above-mentioned work by Davis and $\mathrm{Li}^{86}$ The work is purely illustrative and intended to provoke discussion and further research.

We regress inflation, growth, labour productivity growth, total factor productivity (TFP) growth and real house price growth on their own lags in an ARMA process, together with the age structure variables, first in levels then in differences. Hence, the issue is simply whether a high proportion or increase in proportion of a given age group has been associated over the past half-century with high or low CPI or house price inflation, economic growth or productivity growth. Causality is not proven and further work is needed, as in Davis and $\mathrm{Li}^{87}$ with demographic variables included in fully specified equations or models for the variables concerned. Caution is also needed as the AGE65 cohort is not statistically stationary in most countries - hence more credence should be given to the results in differences.

Concerning results in levels, as shown in Table 2, the results suggest that there is a tendency for the high-saving age group of 40-64 years to accompany relatively low inflation, with the other age groups having no effect. Growth is relatively low when the retired proportion of the population is high, with also some negative effect from the 40-64 years age group. This supports the arguments for slower growth presented in the first section as ageing proceeds. Furthermore, over the last 50 years, a high proportion of elderly persons have accompanied low productivity growth, implying further risks to performance as the population ages. This is true both of labour productivity and total factor productivity. This is despite the fact that a larger retired share of the population may entail a smaller labour force relative to the population, depending on trends in participation. Note on the other hand that there is no major differential in effects on productivity between the younger and older working age population, contrary to the idea that older workers are less adaptable. Finally, in terms of house price increases, the younger cohort exerts a negative influence, perhaps being less

\footnotetext{
${ }^{85}$ United Nations (1998).

${ }^{86}$ Davis and Li (2003).

${ }^{87}$ Ibid.
} 
Table 2 Panel estimation results for levels of demographics and key macroeconomic variables

\begin{tabular}{lccccc}
\hline $\begin{array}{l}\text { Independent } \\
\text { variables }\end{array}$ & Inflation & Growth & $\begin{array}{c}\text { Total factor } \\
\text { productivity } \\
\text { growth }\end{array}$ & $\begin{array}{c}\text { Labour } \\
\text { productivity } \\
\text { growth }\end{array}$ & $\begin{array}{c}\text { Real house } \\
\text { price growth }\end{array}$ \\
\hline $\mathrm{DV}(-1)$ & $0.751^{* *}$ & $0.327^{* *}$ & $0.164^{* *}$ & $0.139^{* *}$ & $0.573^{* *}$ \\
$\mathrm{DV}(-2)$ & $-0.102^{* *}$ & $-0.101^{* *}$ & -0.0427 & $0.0985^{* *}$ & $-0.163^{* *}$ \\
$\mathrm{DV}(-3)$ & -0.00643 & $0.168^{* *}$ & $0.112^{* *}$ & 0.0459 & $-0.178^{* *}$ \\
AGE20 & $9.84 \mathrm{E}-05$ & -0.000543 & -0.0559 & -0.0583 & $-0.00335^{* *}$ \\
AGE40 & $-0.00128^{* *}$ & $-0.000998^{*}$ & -0.0542 & -0.038 & 0.00147 \\
AGE65 & 0.000298 & $-0.00237^{* *}$ & $-0.305^{* *}$ & $-0.301^{* *}$ & $-0.0043^{* *}$ \\
$R^{2}$ & 0.667 & 0.405 & 0.271 & 0.347 & 0.134 \\
SE of regression & 0.0249 & 0.0208 & 2.10 & 2.31 & 0.068 \\
No. of observations/ & $343 / 7$ & $350 / 7$ & $350 / 7$ & $329 / 7$ & $195 / 7$ \\
countries & & & & & \\
\hline
\end{tabular}

Inflation is first difference of the log of CPI, growth is the first difference of the log of GDP, total factor productivity growth is the first difference of the log of TFP, labour productivity growth is the first difference of the log of labour productivity, real house price growth is the first difference of the log of real house prices. DV: (lagged) dependent variable.

SUR, Fixed effects. * indicates significant at $90 \%$ and $* *$ indicates at $95 \%$. Standard errors in parenthesis.

Table 3 Panel estimation results for differences of demographics and key macroeconomic variables

\begin{tabular}{lccccc}
\hline $\begin{array}{l}\text { Independent } \\
\text { variables }\end{array}$ & Inflation & Growth & $\begin{array}{c}\text { Total factor } \\
\text { productivity growth }\end{array}$ & $\begin{array}{c}\text { Labour } \\
\text { productivity } \\
\text { growth }\end{array}$ & $\begin{array}{c}\text { Real house } \\
\text { price growth }\end{array}$ \\
\hline $\mathrm{DV}(-1)$ & $0.754^{* *}$ & $0.361^{* *}$ & $0.193^{* *}$ & $0.182^{* *}$ & $0.49^{* *}$ \\
$\mathrm{DV}(-2)$ & $-0.101^{* *}$ & $-0.0714^{* *}$ & $0.00654^{* *}$ & $0.134^{* *}$ & $-0.0837^{* *}$ \\
$\mathrm{DV}(-3)$ & 0.0109 & $0.194^{* *}$ & 0.152 & $0.0873^{* *}$ & $-0.212^{* *}$ \\
$\Delta$ AGE20 & 0.00303 & 0.00322 & -0.46 & $-0.00799^{* *}$ & $0.0409^{* *}$ \\
$\Delta$ AGE40 & -0.00908 & -0.00195 & $-1.709^{* *}$ & $-0.0197^{* *}$ & $0.0964^{* *}$ \\
$\begin{array}{l}\Delta \text { AGE65 } \\
R^{2}\end{array}$ & $-0.0236^{* *}$ & -0.0136 & $-3.09^{* *}$ & $-0.0334^{* *}$ & $0.152^{* *}$ \\
SE of & 0.667 & 0.349 & 0.2 & 0.311 & 0.186 \\
regression & 0.025 & 0.0218 & 2.2 & 2.38 & 0.066 \\
No. of & & & & $329 / 7$ & $195 / 7$ \\
observations & $343 / 7$ & $350 / 7$ & $350 / 7$ & & \\
countries & & & & & \\
\hline
\end{tabular}

SUR, Fixed effects. * indicates significant at $90 \%$ and $* *$ at $95 \%$. Standard errors in parenthesis.

wealthy, creditworthy and liquid than their older counterparts, as does the elderly cohort (Table 3).

In most cases, the results in differences are consistent with those in levels. Notably, the growth as well as the size of the elderly cohort exerts a negative influence on labour productivity and total factor productivity. There are no significant effects on economic growth, while for inflation the growth of the elderly cohort exerts a negative influence, consistent with common beliefs about the preferences of the elderly for low inflation. In terms of house prices, there is a larger positive effect from the older cohort and the 
smallest from the younger one, consistent with relative resources albeit not with the levels result. As noted, the difference result using nonstationary variables may be more statistically credible.

\section{Conclusions}

As in other OECD countries, pension reform is essential for the future stability of the EU in general and EMU in particular, and its progress is of major concern to central banks as well as Ministries of Finance. We have highlighted a number of risks to financial stability that may occur due to ageing itself with pension reform, and notably when there is a continued reliance on unsustainable pay-as-you-go pension systems. These all require vigilance by central banks, and may require sterilized liquidity assistance or even adjustments in interest rate policy. Risks - and underlying economic performance - will be much worse in the case of no-reform. There are also challenges for counter-inflation policy during the ageing process, as at different points it may generate deflationary and inflationary pressures, while a fiscal crisis would have major repercussions for monetary stability. The transmission process of monetary policy will also enter a state of flux with ageing, although arguably this may be sufficiently gradual to allow central banks time to adapt. On the other hand, our finding of a negative relation between ageing and productivity poses challenges not only to asset prices and to inflation, as set out above, but also to future living standards as the population ages and the labour force shrinks.

\section{References}

Abel, A.B. (2001) Will bequests attenuate the predicted meltdown in stock prices when baby boomers retire?, working paper no.: 01-2, The Wharton School of the University of Pennsylvania and NBER.

Alfonso, A. (2002) Disturbing the fiscal theory of the price level; Can it fit the EU, working paper, Department of Economics, University of Lisbon.

Allen, F. and Gale, D. (1999) 'Bubbles, crises and policy', Oxford Review of Economic Policy 15(3): 9-18.

Allen, F. and Gale, D. (2000) 'Bubbles and crises', Economic Journal 110: 236-255.

Andres, J., Ballabriga, F. and Valles, J. (2002) Non Ricardian fiscal policies in an open monetary union, European Economy Economic Papers No. 169, European Commission, Brussels.

Attanasio, O. and Brugiavini, A. (1999) Social security and household saving, Mimeo, UCL and University of Venice.

Bank of England (2003) Financial Stability Review June 2003, London: Bank of England.

Bikker, J.A. (1996) 'National savings, the current account and ageing populations, a pension fund model', Economic and Financial Modelling (Summer): 1-20.

Bishop, G. (1998) Securitising European Saving, Salomon Smith Barney: London.

Blanchard, O.J. (1993) 'The vanishing equity premium', in R. O'Brien (ed) Finance and the International Economy, Vol. 7, Oxford: Oxford University Press.

Bodie, Z. and Merton, R.C. (1992) 'Pension benefit guarantees in the United States; A functional analysis', in R. Schmitt (ed) The Future of Pensions in the United States, Philadelphia: University of Pennsylvania Press.

Boersch-Supan, A. and Winter, J. (2002) 'Ageing and international capital flows', in H. Herrmann and A. Auerbach (eds) Ageing and Financial Markets, Heidelberg: Springer Verlag - Deutsche Bundesbank.

Bonello, M.C. (2003) 'Population ageing - A major challenge for policy makers', Valletta, Malta: Central Bank of Malta. 
Brooks, R. (2000) What will happen to financial markets when the baby boomers retire?, IMF working paper WP/00/18, International Monetary Fund.

Buckberg, E. (1996) Institutional investors and asset pricing in emerging markets, working paper WP/96/2, International Monetary Fund.

Cutler, D., Poterba, J., Sheiner, L. and Summers, L. (1990) 'An aging society, opportunity or challenge?', Brookings Papers on Economic Activity 1: 1-56.

Dang, T.T., Antolin, P. and Oxley, H. (2001) Fiscal implications of ageing; projections of age-related spending, Economics Department working paper no. 305, OECD, Paris.

Davis, E.P. (1994) 'Market liquidity risk', in D. Fair and R. Raymond (eds) The Competitiveness of Financial Institutions and Centres in Europe, Amsterdam: Kluwer Academic Publishers.

Davis, E.P. (1995) 'Institutional investors, unstable financial markets and monetary policy', in F. Bruni, D. Fair and R. O'Brien (eds) Risk management in Volatile Financial Markets, Amsterdam: Kluwer Academic Publishers.

Davis, E.P. (1999a) 'Russia/LTCM and market liquidity risk', The Financial Regulator 4(2): $23-28$.

Davis, E.P. (1999b) 'Institutionalisation and EMU: Implications for European Financial Markets', International Finance 2: 33-61.

Davis, E.P. (2001) Multiple avenues of intermediation, corporate finance and financial stability, working paper no. 01/115, International Monetary Fund, Washington, DC.

Davis, E.P. (2002) 'Ageing and financial stability', in H. Herrmann and A. Auerbach (eds) Ageing and Financial Markets, Heidelberg: Springer Verlag - Deutsche Bundesbank.

Davis, E.P. (2004a) 'Issues in the regulation of annuities markets', in E. Fornero and E. Luciano (eds) Developing an Annuities Market in Europe, Cheltenham, UK: Edward Elgar.

Davis, E.P. (2004b) 'Financial development, institutional investors and economic performance', in C.A.E. Goodhart (ed) Financial Development and Economic Growth: Explaining the Links, Basingstoke: Palgrave Macmillan.

Davis, E.P. and Hu, Y. (2005) 'Saving, funding and economic growth', in G. Clark (ed) Oxford Handbook of Pension Reform and Investment, Oxford: Oxford University Press.

Davis, E.P. and Li, C. (2003) Demographics and financial asset prices in the major industrial economies, Brunel University working paper no. 03-07.

Davis, E.P. and Steil, B. (2001) Institutional Investors, Boston: MIT Press.

Davis, E.P. and Zhu, H. (2004) Bank lending and commercial property prices, some cross country evidence, BIS working paper no. 150 .

Demirguc-Kunt, A. and Detragiache, E. (1998) Financial liberalisation and financial fragility, IMF working paper no. WP $/ 98 / 83$.

Disney, R. (1996) Can We Afford to Grow Older?, Boston: MIT Press.

Disney, R. (2000) 'Declining public pensions in an era of demographic ageing: Will private pensions fill the gap?' European Economic Review 44: 957-973.

Engelhardt, G. and Poterba, J.M. (1991) 'Demographics and house prices; The Canadian evidence', Regional Science and Urban Economics 21: 539-546.

Engen, E.M. and Lehnert, A. (2000) 'Mutual funds and the US equity market', Federal Reserve Bulletin (December): 797-812.

Fitoussi, J.P. (2003) Monetary policy, the promotion of growth and the SGP in an ageing society, briefing paper no. 4-14, November 2003, European Parliament Committee for Economic and Monetary Affairs.

Fortune, P. (1998) 'Mutual funds, part II; fund flows and security returns', New England Economic Review (Jan/Feb): 4-22.

Fukao, M. (2002) Barriers to financial restructuring; Japanese banking and life insurance industries, paper presented at the NBER Conference on Structural Impediments to Growth in Japan, Tokyo, 18-19 March 2002.

Gilson, S., Kose, J. and Lang, L. (1990) 'Troubled debt restructurings', Journal of Financial Economics 27: 315-353.

Greenspan, A. (1999) 'Do efficient financial markets mitigate financial crises?', speech to the Financial Markets Conference of the Federal Reserve Bank of Atlanta, 19 October.

Hargraves, M., Schinasi, G.J. and Weisbrod, S.R. (1993) Asset price inflation in the 1980s: A flow of funds perspective, IMF working paper, no. WP/93/77. 
Hellman, T.F., Murdock, K. and Stiglitz, J.E. (2000) 'Liberalisation, moral hazard in banking, and prudential regulation; Are capital requirements enough?', American Economic Review 90: 147-165.

Hendershott, P.H. (1991) 'Are real house prices likely to decline by 47\%?', Regional Science and Urban Economics 21: 553-565.

Holzmann, R. (1997) Pension reform, financial market and economic growth, preliminary evidence from Chile, International Monetary Fund staff papers (June), International Monetary Fund, Washington.

Hoshi, T., Kashyap, A. and Scharfstein, D. (1993) The choice between public and private debt; An analysis of post deregulation corporate financing in Japan, working paper no. 4211, National Bureau of Economic Research.

IMF (1998) World Economic Outlook and International Capital Markets, Interim Assessment December 1998 - Financial Turbulence and the World Economy, International Monetary Fund: Washington, DC.

IMF (2001) Experience with the insurance core principles assessments under financial sector assessment programs, IMF/World Bank August 21, 2001.

Kohl, R. and O'Brien, P. (1998) The macroeconomics of ageing, pensions and savings: A survey, OECD paper, AWP 1.1.

Loayza, N., Schmidt-Hebbel, K. and Serven, L. (2000) 'What drives private savings around the world?', Review of Economics and Statistics 82: 165-181.

Mankiw, N.G. and Weil, D.N. (1989) 'The baby boom, the baby bust and the housing market', Regional Science and Urban Economics 19: 238-258.

Masson, P., Bayoumi, T. and Samiei, H. (1995) International evidence on the determinants of private saving, IMF working paper no. W95/51.

Masson, P. and Tryon, R.W. (1990) 'Macroeconomic effects of projected population ageing in industrial countries', IMF Staff Papers 37: 453-485.

McMorrow, K. and Roeger, W. (2002) EU pension reform, an overview of the debate and an empirical assessment of the main policy reform options, European Economy Economic Papers no. 162, European Commission, Brussels.

McMorrow, K. and Roeger, W. (2003) Economic and financial market consequences of ageing populations, European Economy Economic Papers no. 182, European Commission, Brussels.

Miles, D.K. (2002) 'Ageing and monetary stability', in H. Herrmann and A. Auerbach (eds) Ageing and Financial Markets, Heidelberg: Springer Verlag - Deutsche Bundesbank.

Neuberger, A. (1999) 'Long term savings flows and the capital market', Morgan Stanley Dean Witter Global Pensions Quarterly, January 1999.

Poterba, J.M. (2001) 'Demographic structure and asset returns', Review of Economics and Statistics 83: $565-584$.

Poterba, J.M. (2004) The impact of population ageing on financial markets, NBER working paper no. 10851.

Regling, K. and Costello, D. (2003) The economic and budgetary implications of ageing populations; An EU perspective, presentation to conference organised by DG-Economic and Financial Affairs, Brussels, 4-5 March 2003.

Salo, S. (2003) The relevance of fiscal soundness for monetary stability, remarks to SUERF Conference on Securing Financial Stability, Problems and Prospects for New EU Members, Central Bank of Malta, 28 March 2003.

Schieber, S.J. and Shoven, J.B. (1994) The consequences of population aging on private pension fund saving and asset markets, NBER working paper 4665.

Shiller, J.R. (2000) Irrational Exuberance, Princeton: Princeton University Press.

Turner, D., Giorno, C., De Serres, A., Vourch, A. and Richardson, P. (1998) The macroeconomic implications of ageing in a global context, Economics Department working paper no 193, OECD, Paris.

United Nations (1998) Demographic data 1998, UN, New York.

Wattenburg, B. (1987) The Birth Dearth, New York: Pharos Books.

Woodford, M. (2001) 'Fiscal requirements for price stability', Journal of Money, Credit and Banking 33: $669-728$.

Young, G. (2002) The implications of an ageing population for the UK economy, Bank of England working paper. 